DOI https://doi.org/10.18551/rjoas.2018-02.13

\title{
INVESTMENT DEPOSITS DECISION-MAKING IN BANK: A BEHAVIORAL FINANCE PERSPECTIVE
}

\author{
Hanopia Baiq Lita* \\ Master Management Program, University of Mataram, Indonesia \\ Surasni Ni Ketut, Hidayati Siti Aisyah \\ Faculty of Economics and Business, University of Mataram, Indonesia \\ *E-mail: balitha.hanopia@gmail.com
}

\begin{abstract}
This research was conducted using behavioral finance theories. The objectives of this research was to analyze determining factors of investment deposits decision-making for the depositor, and to analyze the most dominant factor of investment deposits decision-making in Bank NTB of Pejanggik Principle Branches. The instrument of this research was questionnaire with the total sample of 90 respondents who were the deposit customers. The research results show that deposits' interest, gain and cost, feelings of disappointment and satisfaction, worries, reluctances, good companies, budget allocation, self-control, net interest income, belief in net interest income, overestimate and underestimate are factors determining investment deposits decision-making in Bank NTB of Pejanggik Principle Branches. Dominant factors determining investment deposits decision-making are deposits cost, interest and feelings of satisfaction, budget allocation, overestimate and self-control. Those factors are included in the factor group of deposits cost.
\end{abstract}

\section{KEY WORDS}

Behavioral finance, investment, decision-making, deposit, bank.

Investment is a placement of the number of current funds with the expectation of getting profits in the future (Halim, 2005). Deposits investment is one kind of financial asset investment that is widely-known by society. Nowadays, deposits investment development is getting higher. Bank NTB is a regional bank offering deposit program in which the deposit disbursement should not conduct when the deposit due date and also is not imposed penalty cost, it only asks daily interest as per total time funds placement. Even though a customer deposit of Bank NTB of Pejanggik Principle Branches is given offerings to not pay penalty cost when disbursing the deposit prior to the expiry of the agreement, but several of them still disburse the deposit before the time. In some cases, Bank NTB of Pejanggik Principle Branches cannot hold a priority customer who gets a special rate. As a result, it frequently happens instability of deposits total development in Bank NTB of Pejanggik Principle Branches, especially retail deposit customer. This total deposit instability is recurring annually, whereas an asset development of Bank NTB of Pejanggik Principle Branches has been better. This indicates that there is still another factor influencing customer of Bank NTB of Pejanggik Principle Branches to invest, especially investment deposits. Another cause such psychological factor also influences someone to invest.

Investment analysis using psychological science is known as behavioral finance (Manurung, 2012). Behavioral finance is a study of how people actually behave to make a decision related to finance, in addition, this also explains how people invest or do an activity related to the finance influenced by a psychological factor (Nofsinger, 2005). This can be related to the situation of Bank NTB of Pejanggik Principle Branches, in which total asset increases but total deposits tend to be less stable. Behavioral finance can be related to the factor influencing depositor on investment decision-making, and finally, forming a behavioral finance of each depositor to invest his/her funds in Bank NTB of Pejanggik Principle Branches. 
Shefrin (2007) categorizes behavioral finance aspects playing role in investment decision-making i.e bias, heuristic, and framing effect. If changed into general variable, behavioral finance contains several variables that can be used as a consideration by investor to make a decision, among other, agency, overconfidence, anchoring, gambler's fallacy, loss aversion, regret aversion, mental accounting, dering speed and etc. (Abedini et al., 2014). A study conducted by Luong et al (2011) reveals that the most determining variable of investor's assessment system more refers to the prospect theory consisted of regret aversion, loss aversion, and mental accounting. Mental accounting is a decision in which the investor considers cost and benefit during the investment decision making (Nofsinger, 2005). A not happy feeling if investment selling price is cheaper than the purchase price, and a sensitive feeling towards loss than benefits is called loss aversion. In addition, loss aversion has a higher level of a feeling of disappointment when suffering loss than the level of satisfaction obtained after getting the same amount of benefits. Regret aversion variable influencing an investor to make an investment is as follow. According to Anastasia et al., (2015) regret aversion is an investor's most-determining variable on investment decisionmaking. Regret aversion makes investor too much worry and do not want to make another option, then causes investor more likes good companies. However, Abedini et al. (2014) found that regret aversion, loss aversion, and mental accounting generally have a negative influence on investment performance from all investors, while overconfidence and anchoring are an effective factor in investment. According to Shefrin (2007), anchoring is a condition in which an investor makes a numeric prediction as a reference, and then makes an adjustment but tends to not be able to make the proper adjustment. While overconfidence, according to Nofsinger (2005), is a feeling of overconfidence that brings overestimate and underestimate characteristic.

In addition to the variable consisting of mental accounting, loss aversion, regret aversion, overconfidence, and anchoring, there is also self-control grouped into one of the considered factors in investment decision-making. As in Riaz and lqbal's (2015) research which indicates that overconfidence, optimism bias, and self-control have a positive influence on the investor's investment decision-making. Self-control is a variable which relates to the financial management, in which an investor spend his/her money in accordance with the needs not wants (Baumeister, 2002).

According to that phenomenon, research gap and investment deposits data in Bank NTB of Pejanggik Principle Branches that tends to be fluctuating so that conducted a research on investment decision-making in PT. Bank NTB of Pejanggik Principle Branches based on the behavioral finance perspective, with aims as follow:

- To analyze determining factors of investment deposits decision-making of Bank NTB of Pejanggik Principle Branches' depositor;

- To analyze the most dominant factor on investment deposits decision-making in Bank NTB of Pejanggik Principle Branches.

\section{LITERATURE REVIEW}

Behavioral Finance. According to Ricciardi (2000), behavioral finance is an area of expertise associating interaction of various sciences within and continuously integrated so that the discussion is not given isolation. Three aspects that influence someone's behavioral finance are psychology, sociology, and finance. Pompian (2006) separates behavioral finance into two sub-topics which will ease people to understand the benefits of learning behavioral finance. The first sub-topic is micro and macro behavioral finance. According to Lintner (1998), behavioral finance is a study of how people behave and act the existing information in the effort of making a decision which can optimize the rate of return considering associated risk within (element of character and people behavior is an a determining factor in investing).

Iramani (2011) through his research entitled Capitalist Behavior Model towards Risk and Investment Type in the Banking Sector (Technology-Based Behavioral Finance Study) uses several variable indicators, among other, overconfidence, data mining, herd-like 
behavior, status quo, social interaction, emotion, mental accounting, vividness bias, anchoring, representativeness, familiarity, pride and regret, considering the past, fear and greed, as well as self-control. This research shows that there are five factors which form capitalist behavior of banking sector i.e investment security, experience and skill in investment, social interaction consideration and prudential investment, coziness, and emotion.

Limanjaya's (2014) research reveals that the majority of respondent gives a positive response towards all research elements consisted mental accounting, representativeness, familiarity, considering the past, overconfidence, data mining, social interaction, fear and greed, status quo, and emotion. A study conducted by Riaz and lqbal (2015) entitled Impact of Overconfidence, Illusion of Control, Self Control and Optimism Bias on Investor Decision Making; Evidence from Developing Markets uses several variables, among other overconfidence, an illusion of control, self-control and optimism bias. The research result shows that overconfidence, self-control and optimism bias have a positive influence on investor decision making. In addition, Stromback et al., (2017) find that self-control has a positive influence on financial behavioral.

Prospect Theory. Prospect Theory is a theory developed by Kahnemen and Tversky (1979) and is a theory describing how someone individually evaluates profits and loss. Pompian (2006) also states that prospect theory also includes several bias concepts explained i.e framing, loss aversion, regret aversion, mental accounting, and self-control. However, this research uses several bias concepts, i.e. mental accounting, loss aversion, and self-control.

Mental accounting is a psychological factor that can be someone's tolls to control his/herself that causes people think rationally so that able to make a good decision (Thaller et al., 2008). An investor having mental accounting in transaction decision making is an investor considering cost and benefit from the decision made (Nofsinger, 2005). While regret aversion is described as a term to illustrate a feeling of disappointment after making a decision in a not specified decision in which the decision changes into the bad option, even though it is based on the right information. In addition, there is loss aversion factor which is a feeling of displeasure to sell his/her asset with lower selling price than the purchase price, this is categorized into loss aversion behavior (Ritter, 2003). An investor also has a tendency to sell his/her asset too quickly if thinking that $s /$ he has obtained benefits or kept longer if suffering loss (Shefrin et al., 2000). An investor also tends to feel hurt when suffering loss than gain despite in the same number (Tilson, 2005). Self-control is a behavioral finance factor relating to the financial management, such as resisting the desires or encouragements to spend money in unreasonable amount become to spend money based on our needs not wants (Baumeister, 2002). In addition, according to Karlsson (1998), self-control is also used to avoid short-term preference to reach the long-term one and can be a strategy to prevent waste of money in allocating finance and planning investment.

Heuristic Theory. Heuristic tells how an investor has believed bias that can influence him to think and make a decision (de Bont et al., 2008). According to Ritter (2003), heuristic also can be referred to the rule of thumb or general provision relating to the character to help the decision-making process. Heuristic comprises five biases i.e anchoring, representativeness, availability bias, gambler fallacy and overconfidence (Luong et al., 2011). Yet this research's heuristic bias used is anchoring and overconfidence.

Anchoring is a behavior referring to the decision-making process when quantitative assessment needed and this assessment is influenced by investors' personal suggestion (Johnsson et al., 2002). In addition, Pompian (2006) mentions that anchoring and adjustment bias occurs when an investor is needed to estimate something unknown before so that the investor makes a provision of default number or anchor as the basis of estimation. Shefrin (2007) mentions that anchoring is a condition in which an investor makes a numeric prediction in beginning as the reference. De Bondt et al., (2008) states that anchoring is a form of bias that only believes in one kind of information so that the investment decision is based on the particular information only. While overconfidence, according to Nofsinger (2005), is the quality of being over certain which can grow overestimate characteristic 
towards investor's knowledge and underestimates towards other investor's prediction, since it more believes in investor's knowledge.

Investment Decision Making. Decision making is defined as a whole process, not merely a simple action that only chooses a number of alternatives (Coulter and Robbins, 2007). While Handoko (2011) defines decision making as the determiner of a set of activity to reach the expected result and to finish a problem.

A study conducted by Schran (2012) reveals that reluctances of a regret aversion are a considered factor in the decision-making process. Zelenber et al., (1996) concludes that investor has a tendency to avoid disappointment in investment decision making, and regret aversion is an essential motivation in several stages of investment decision-making process.

Gazel (2015) gets a result that investor tends to avoid behavior creating regret and find a behavior that can result in benefits or pride. Regret aversion is said causing investment error since it is not always applied "buy low, sell high" theory. Abedini et al., (2014) concludes that only loss aversion which is positively a natural behavior owned by an investor. In addition, there is also a research result stating that overconfidence and anchoring are two factors with a positive effect on investment.

A study conducted by Anastasia et al., (2015) shows that regret aversion becomes the first thing the investor considers to invest presidential property in Surabaya and loss aversion is the second factor to consider. While mental accounting is the third consideration in residential investment decision making in Surabaya. Regret aversion is the most influential variable in investment decision making.

Saraswati (2015) gets a result that anchoring and adjustment variable, as well as conservatism bias, have a positive influence on investment decision making based on the risk tolerance. If based on the company image, anchoring, adjustment and conservatism bias have a negative influence on investment decision making. While Kartini and Nugraha's (2015) research uses three variables i.e illusion of control, overconfidence, and emotion as well as 86 respondents. The research result shows that overconfidence has a positive influence on investment decision making.

Deposit. Deposit is servings whose withdrawal only can be conducted at a particular time based on the agreement between a customer and bank staff (Kasmir, 2011). Kind of deposit is among other deposit on call and time deposit.

\section{METHODS OF RESEARCH}

This was exploratory-descriptive quantitative research. This research finds and describes new relationships within a wide an complex problem. The sample used was the customer of retail deposit (company) of PT. Bank NTB of Pejanggik Principle Branches with 90 respondents. Data collection method used was survey method.

The sampling technique used to conduct this research was non-probability sampling technique, and the data collection technique used was using questionnaire. Analysis tool used was factor analysis. Factor analysis is a technique used to find factors being able to explain the relationship or correlation between various independent factor observed (Widarjono, 2010).

This research uses fourteen factors from six variables (mental accounting, regret aversion, loss aversion, overconfidence, anchoring, and self-control). Those fourteen factors are among other deposits interest, deposits gain, deposits cost (mental accounting), a feeling of disappointment, loss aversion, worries, reluctances, good companies (regret aversion), budget allocation, self-control, belief on net interest income, anchoring, overestimate and underestimate (overconfidence).

\section{RESULTS AND DISCUSSION}

Respondents Characteristic Description. This research used several respondent characteristics, consisted of both genders, age, income, total deposit and time of deposit. This research found $27.8 \%$ or as many as 35 respondents are men and $72.2 \%(65)$ is 
women. The majority of the respondent is above 40 years old and their income ranges between 2.500.000 IDR (\$186.5) to 3.500.000 IDR (\$261.1). While for deposits value, the majority of the respondents deposit their money in the range of 25.000 .000 IDR to 50.000.000 IDR. Time deposit used by respondents at most 3-month-time deposit is $86.7 \%$ (78 respondents).

Bartlett's Test of Sphericity and Kaiser Meyer Olkin. Bartlett's test of Sphericity (BTS) is a test used to see if the variable correlates or not within a population. BTS value obtained was 517.941 which means there is a relationship between the observed variable so that the analysis factor can be used to conduct this research.

Table 1 - MSA Last Value of Research Variable

\begin{tabular}{|l|c|c|}
\hline \multicolumn{1}{|c|}{ Indicator } & MSA Value & Description \\
\hline Deposits Interest & $0.880(\mathrm{a})$ & Fixed \\
\hline Deposits Benefit & $0.624(\mathrm{a})$ & Fixed \\
\hline Deposits Cost & $0.806(\mathrm{a})$ & Fixed \\
\hline A Feeling of Disappointment & $0.812(\mathrm{a})$ & Fixed \\
\hline A Feeling of Satisfied / Level of Satisfaction & $0.896(\mathrm{a})$ & Fixed \\
\hline Worries & $0.894(\mathrm{a})$ & Fixed \\
\hline Reluctances & $0.845(\mathrm{a})$ & Fixed \\
\hline Good Companies & $0.874(\mathrm{a})$ & Fixed \\
\hline Budget Allocation & $0.807(\mathrm{a})$ & Fixed \\
\hline Self-Control & $0.821(\mathrm{a})$ & Fixed \\
\hline Net Interest Income & $0.848(\mathrm{a})$ & Fixed \\
\hline A Belief in Net Income Interest & $0.841(\mathrm{a})$ & Fixed \\
\hline Overestimate & $0.819(\mathrm{a})$ & Fixed \\
\hline Underestimate & $0.756(\mathrm{a})$ & Fixed \\
\hline
\end{tabular}

Source: Processed Primary Data, 2017.

This research results in MSA (Measure of Sampling Adequacy) value used to measure sample adequacy. MSA value obtained for each factor is above 0.5. According to Malhotra (1996), if MSA value is higher or equal to 0.5, that indicator or variable can be still used in factor analysis. Hence this preliminary MSA last value shows that there are 14 factors that can be used to the next stage of extraction stage as seen in table 1.

Extraction Factor. Extraction factor is a method used to reduce data from several indicators to result in a little more factor that can explain a correlation between the observed indicator (Widarjono, 2010).

If MSA value is higher than or equal to 0.5 , the indicator analyzed in extraction factor stage can be used to the next step (Malhotra, 1996). The result of the first stage factor extraction can be seen in table 2 .

Table 2 - The First Research Factor Extraction Result

\begin{tabular}{|l|c|c|}
\hline \multicolumn{1}{|c|}{ Indicator } & MSA Value & Description \\
\hline Deposits Interest & $0.880(\mathrm{a})$ & Fixed \\
\hline Deposits Benefits & $0.624(\mathrm{a})$ & Fixed \\
\hline Deposits Cost & $0.806(\mathrm{a})$ & Fixed \\
\hline A Feeling of Disappointment & $0.812(\mathrm{a})$ & Fixed \\
\hline A Feeling of Satisfied / Level of Satisfaction & $0.896(\mathrm{a})$ & Fixed \\
\hline Worries & $0.894(\mathrm{a})$ & Fixed \\
\hline Reluctances & $0.845(\mathrm{a})$ & Fixed \\
\hline Good Companies & $0.874(\mathrm{a})$ & Fixed \\
\hline Budget Allocation & $0.807(\mathrm{a})$ & Fixed \\
\hline Self-Control & $0.821(\mathrm{a})$ & Fixed \\
\hline Net Interest Income & $0.848(\mathrm{a})$ & Fixed \\
\hline A Belief in Net Interest Income & $0.841(\mathrm{a})$ & Fixed \\
\hline Overestimate & $0.819(\mathrm{a})$ & Fixed \\
\hline Underestimate & $0.756(\mathrm{a})$ & Fixed \\
\hline
\end{tabular}

Source: Processed Primary Data, 2017. 
According to the result of extraction factor, it gets fourteen factor having MSA value higher than 0.5. It means that the factor used is still included in the group having a correlation with the research. Therefore, those fourteen factors can be used.

This factor analysis also results in total result of variance explained telling about the size of variance which can be explained by the formed factor. Total variance explained can form 4 factor groups. This formed factor group will base on the eigenvalue if it is $\geq 1$ the indicator is included in the factor development, but if eigenvalue is $<1$, it is not included in the factor development (Widarjono, 2010).

Factor Rotation. During the factor rotation stage, we can obtain any factor including in the formed factor groups and mention the name of every those factor groups. After rotating those fourteen factors using varimax rotation method, it gets four-factor groups below:

- The first-factor group is deposit cost, consisted of deposits interest factor by 0.540 , deposit cost by 0.829 , a feeling of satisfaction by 0.701 , budget allocation by 0.706 , self-control by 0.629 and overestimate indicator with the lowest value by 0.432 .

- The second-factor group is called a belief on net interest income, consisted of net interest income factor by 0.650 , beliefe on net interest income by 0.737 and indicator of underestimate by 0.620 .

- The third-factor group is called good companies factor, this consists of worries by 0.489 , reluctances by 0.655 and indicator of good companies by 0.674 .

- The fourth-factor group is the last factor formed, it is called factor group of deposits gain, consisted of deposit gain factor by 0.834 and feeling of disappointment factor by 0.750 .

Hence if seen from the rotation result, it is known that all factors used in this research determine the investment decision making in Bank NTB of Pejanggik Principle Branches. The following table 3 indicates the result of the general factor rotation.

Table 3 - Research Rotation Result

\begin{tabular}{|c|c|c|c|c|}
\hline \multirow{2}{*}{ Indicator } & \multicolumn{3}{|c|}{ Component } \\
\cline { 2 - 5 } & 1 & 2 & 3 & 4 \\
\hline Deposits Interest & $\mathbf{0 . 5 4 0}$ & 0.355 & 0.175 & 0.323 \\
\hline Deposits Gain & 0.035 & 0.094 & 0.023 & $\mathbf{0 , 8 3 4}$ \\
\hline Deposits Cost & $\mathbf{0 . 8 2 9}$ & 0.093 & 0.001 & 0.154 \\
\hline A Feeling of Disappointment & 0.322 & 0.223 & 0.206 & $\mathbf{0 . 7 0 5}$ \\
\hline A Feeling of Satisfaction & $\mathbf{0 . 7 0 1}$ & 0.114 & 0.382 & 0.023 \\
\hline Worries & 0.305 & 0.288 & $\mathbf{0 . 4 8 9}$ & 0.292 \\
\hline Reluctances & 0.188 & -0.062 & $\mathbf{0 . 6 5 5}$ & 0.369 \\
\hline Good Companies & -0.440 & 0.127 & $\mathbf{0 . 6 7 4}$ & -0.047 \\
\hline Budget Allocation & $\mathbf{0 . 7 0 6}$ & 0.229 & 0.297 & 0.083 \\
\hline Self-Control & $\mathbf{0 . 6 2 9}$ & 0.193 & 0.376 & 0.140 \\
\hline Net Interest Income & -0.105 & $\mathbf{0 . 6 5 0}$ & 0.346 & 0.341 \\
\hline Beliefe on Net Interest Income & 0.313 & $\mathbf{0 . 7 3 7}$ & 0.004 & 0.231 \\
\hline Overestimate & $\mathbf{0 4 3 2}$ & -0.745 & -0.004 & 0,031 \\
\hline Underestimate & 0.106 & $\mathbf{0 . 6 2 0}$ & 0.615 & -0.135 \\
\hline
\end{tabular}

Source: Processed Primary Data, 2017.

Dominant Factor Determining Investment Deposits Decision-Making. Factor analysis result, which is a table of total variance explained, can describe the percentage of each factor group formed. The higher the extraction of sums of squared loadings value, the bigger the chance to be the representative of a variable (Widarjono, 2010). Extraction sum of squared loadings can indicate how large of the formed factor group tells the existing factor variance. According to the extraction sums of squared loadings, it is known that deposits value is the most dominant factor group for determining deposits investment decision making in Bank NTB of Pejanggik Principle Branches since having percentage of variance by $40.71 \%$, this factor group consists of deposits interest, deposits cost, a feeling of satisfaction, budget allocation, self control and overestimate. 
This research uses fourteen factors consisted of deposits interest, deposits gain, deposits cost, a feeling of disappointment, a feeling of satisfaction or level of satisfaction, budget allocation, self-control, net interest income, a belief in net interest income, overestimate and underestimate. Those fourteen factors form four-factor groups i.e deposit cost factor group, a belief on net interest income factor group, good companies factor group and deposit gain factor group.

Deposits cost is a factor group in which the factor within is from mental accounting variable, loss aversion, self-control and overestimate. While the factor group of a belief in net interest income has a factor from the variable of anchoring and overconfidence. Good companies' internal factor is from regret aversion variable. The last factor group formed is deposit benefits consisting of a factor from the variable of mental accounting and loss aversion. According to that factor group formation, it is seen that every factor from each variable used enters into the factor group determining the deposit investment decision making. It means that mental accounting, loss aversion, regret aversion, self-control, anchoring, and overconfidence are considered to determine deposit investment decision. The prior study conducted by Anastasia and Sumtoro (2015) also indicates the same result in which the variable consisted of regret aversion, loss aversion, and mental accounting determine the investment decision making. The same result is also proposed by Riaz and Iqbal (2015), in which the result shows that overconfidence and self-control have a positive influence on investor decision making. It means that variable and factors within determine the investment decision making. Ranjbar et.al, (2014) through his research also reveals that anchoring and overconfidence have a positive influence on investment so that can decide investment decision making.

A dominant factor group of this research is deposit cost factor while the factor is deposit interest, deposits cost, a feeling of satisfaction, budget allocation, self-control and overestimate. This analysis result can be seen in the table of the analysis result of extraction sums of squared loadings at variance part, in which the dominant factors are included in the factor of deposits cost with the percentage of $40.717 \%$. Mental accounting is assumed to place the money into a particular group based on the purpose and considering cost and benefits (Nofsinger, 2005). The same result is also obtained by Anastasia et al., (2015) in which mental accounting is one of the variables in behavioral finance determining the investment decision making. A feeling of satisfaction is a factor from loss aversion variable, which means loss aversion variable includes the dominant factor group to determine deposit investment decision. As in Ranjbar's et al., (2014) research which gets a result that loss aversion is positively a natural behavior owned by an investor, so that loss aversion variable is one of the variables determining investment decision making. Budget allocation and selfcontrol factor are factors coming from self-control variable. These two factors determine depositor in investment decision making in Bank NTB of Pejanggik Principle Branches and include in the factor group of deposits cost. Dewi (2004) proposed that self-control is defined as how strength someone to hold his/her value and belief as a reference to behave or make a decision. Riaz and lqbal (2015) also state that-self control has a positive influence on investment decision making, which means the factors in form of budget allocation and selfcontrol also have a positive influence on investment decision making, while overestimate is a factor from overconfidence variable.

It means that overconfidence is a variable including in the deposits cost factor group, which is a dominant factor group determining investment decision making in Bank NTB of Pejanggik Principle Branches. Overestimate is a condition in which depositor feels having much more other information, so that causes him to feel having the policy to make the best decision. Overconfidence can direct into overestimating characteristic (Nofsinger, 2005). The same result was also found by Kartini and Nugraha (2015), in which overconfidence has a positive influence on investment decision making.

This research forms the second-factor group, which is factor group of a belief in net interest income. Factor group of belief in net interest income is consisted of net interest income factor, a belief in net interest income, and underestimate. Net deposits interest income and a belief in net interest income are factors from anchoring variable which also 
determine deposits investment decision, even though the related factor is not the dominant ones. Like a study conducted by Saraswati (2015) indicating that anchoring has a positive influence on investment decision making.

The third-factor group formed is good companies factor group, consisted of worries factor, reluctances, and good companies. These factors are from regret aversion variable which includes the factor group determining investment deposits decision making in Bank NTB of Pejanggik principles Branches, even though it is not included in the dominant factor. This is also in relation to what proposed by Zelenbarg et al., (1996) which means that regret aversion is an essential motivation in several processes of investment decision-making stage.

Deposit gain is the fourth-factor group formed. Deposit benefits factor group consists of deposit benefits factor and a feeling of disappointment belief. These two factors are from mental accounting variable and loss aversion.

\section{CONCLUSION AND SUGGESTIONS}

According to the research result, it concludes:

Factors a determining investment deposits decision making are deposits interest, deposits gain, deposits cost, a feeling of disappointment, a feeling of satisfaction and level of satisfaction, worries, reluctances, good companies, budget allocation, self-control, net interest income, belief on net interest income, overestimate and underestimate. According to the factor analysis that has been conducted, so these factors are formed into four-factor groups i.e. deposits cost factor group, factor group of belief in net interest income, factor group of good companies and factor group of deposit benefits.

The most dominant factors are deposits cost, deposits interest, a feeling of satisfaction or level of satisfaction, budget allocation, self-control and overestimate. These factors include the factor group of deposits cost

The followings are the suggestions which can be done according to the research from several interest sides, among other:

Practice interest means in the effort of increasing the amount of deposit ration of Bank NTB of Pejanggik Principle Branches, especially retail deposit, the policyholder is suggested to pay attention factors determining investment decision making by deposit customers, especially retail deposit customer and is not only from promotion side or continuing old customers. Those factors are deposits interest, deposits cost, a feeling of disappointment, a feeling of satisfaction or level of satisfaction, worries, reluctances, good companies, budget allocation, self-control, belief on net interest income and overestimate. In addition is customer loyalty, especially old deposit customers and priority customer should be paid attention to more draw attention and increase total deposit ration placed in Bank NTB of Pejanggik Principle Branches.

Theoretical interest means this research uses several variables from behavioral finance, among other mental accounting, regret aversion, loss aversion, self-control, anchoring and overconfidence and there are also fourteen factors included within to use in this research.

For further researchers who want to conduct a study on behavioral finance can use variables and factor included within. In addition, the researchers also can find much more subject with different company field and use variable which different to what used in this research.

\section{REFERENCES}

1. Abedini, B., Jamali, M., Ranjbar, M, \& Hossein. (2014). Analyzing The Effective Behavioral Factors On The Investor' Performance In Tehran Stock Exchange (THE). International Journal of Art and Hummanity Science (IJAHS), 1 (2), 80-86. e-ISSN: 23495235. 
2. Anastasia, N., \& Sumtoro, A. (2015). Perilaku Keuangan dalam Pengambilan Keputusan Berinvestasi Properti Residensial di Surabaya. Finesta 3 (1), 41-45.

3. Baumeister, R, F. (2002). Yielding to Temptation: Self Control Failure, Impulsive Purchasing, and Consumer Behavior. Journal of Consumer Research, 28, 670 - 676.

4. Coulter, M., \& Robbins, S. P. (2007). Manajemen. Edisi Kedelapan. Jakarta: PT Indeks.

5. Dewi, A. (2004). Manajemen Keuangan Perusahaan. First Edition. Jakarta, Indonesia: Ghalia.

6. De Bondt, W., Muradoglu, G., Shefrin, H., \& Staikouras, S.K. (2008). Behavioral Finance: Quo Vadis?. Journal Of Applied Finance, 1-15.

7. Gazel, S. (2015). The Regret Aversion As An Investor Bias. International Journal of Business and Management Studies, 4 (2), 419-424.

8. Halim, A. (2005). Analisis Investasi Jakarta. Jakarta: Salemba Empat.

9. Handoko, T. H. (2011). Manajemen. Edisi kedua. Yogyakarta: BPFE-Yogyakarta.

10. Iramani, Rr. (2011). Model Perilaku Pemodal terhadap Risiko dan Jenis Investasi pada Sektor Perbankan (Studi Perilaku Keuangan Berbasis Psikologi). Jurnal Aplikasi Manajemen, 9 (1).

11. Johnsson, M., Lindblom, H., \& Platan, P. (2002). Behavioral Finance and the Change of Investor Behavior during and After the Speculative Bubble at the End of the 1990s. Tesis Universitas Lund.

12. Kahneman, D., \& Twersky, A. (1979). Prospect Teori: An Analysis of Decision under Risk. Econometrica, 47(2), 263-291.

13. Karlsson, N. (1998). Mental Accounting and Self Controlling. Psychological Reports 28 (2), 1- 15

14. Kartini, \& Nugraha, N, F. (2015). Pengaruh Illusion of Control, Overconfidence dan Emotion Terhadap Pengambilan Keputusan Investasi Pada Investor di Yogyakarta. Jurnal Inovasi dan Kewirausahaan, Vol. 4, No.2, Mei 2015, hal. 115-123. Prodi Manajemen Universitas Islam Indonesia.

15. Kasmir. (2010). Dasar-Dasar Perbankan. Jakarta: Rajawali Pers.

16. Limanjaya, S. R. (2014). Perilaku Investor Saham, Reksadana dan Deposito: Suatu Studi Deskriptif. Jurnal Ilmiah Mahasiswa Universitas Surabaya, 3 (1).

17. Lintner, G. (1998). Behavioral Finance: Why Investors Make Bad Decisions. The Planner $13(1), 7-8$.

18. Luong, L, Phuoe, H., \& Doan, T.T. (2011). Behavioral Factors Influencing Individual Investors'Decision Making and Performance. Unpublished Thesis, Umea School of Business.

19. Malhotra, N, K. (1996). Marketing Research An Applied Oriented. Second Edition. New Jersey: Prentice Hall.

20. Manurung, A. H. (2012). Teori Investasi: Konsep dan Empiris. Indonesia: PT. Adler Manurung Press.

21. Nofsinger, J. R. (2005). Psychologi of Investing. Second Edition.. New Jersey: Precentice-Hall Inc.

22. Pompian, M. M. (2006). Behavioral Finance and Wealth Management: How to Build Optimal Portfolios That Account for Investor Biases. New York: Wiley Finance.

23. Riaz, T., \& Iqbal, H. (2015). Impact of Overconfidence, Illusion of control, Self Control and Optimism Bias on Investors Decision Making; Evidence from Developing Markets. Research Journal of Finance and Accounting 6 (11).

24. Ricciardi, V. (2000). A Research Starting Point for a New Scholar: A Unique Perspective of Behavioral Science. Working Paper. Golden State University.

25. Ritter, J. R. (2003). Behavioral Finance. Pasific-Basin Finance Journal 11 (4).

26. Saraswati, A. R. (2015). The Effect of Anchoring and Adjustment Bias and Conservatism Bias of Investment Decision Making. Skripsi Pendidikan Akuntansi, Universitas Negeri Malang.

27. Schran, F. (2012). The Influence of Regret on Decision Making: Theory and Experiment. The Bonn Journal of Economics 2 (2), 45-58. 
28. Shefrin, H., \& Statman, M. (2000). Behavioral Portofolio Theory. The Journal of Financial and Quantitative Analysis, 35(2), 127-151.

29. Shefrin, H. (2007). Behavioral Corporate Finance: Decision That Create Value. New York: McGrwall-Hill/Irwin.

30. Stromback, C., Lind, T., Skagerlund, K., Vastfjall, D., \& Tinghog, G. (2017). Does selfcontrol predict financial behavior and financial well-being?. Journal of Behavioral and Experimental Finance 14, 30-38.

31. Thaler, R, H., \& Sunstein C.R. (2008). Nudge: Improving Decisions About Health, Wealth, and Happiness. New Haven, CT: Yale University Press.

32. Tilson, W. (2005). Applying Behavioral Finance to Value Investing. Artikel T2. Partner LLC. http://zllwww.T2PartnerLLC.com

33. Widarjono, A. (2010). Analisis Statistika Multivariat Terapan. Yogyakarta: UPP STIM YKPN.

34. Zeelenberg, M., Beattie, J., Van der Plight, J, \& de Vries, N. K. (1996). Consequences of Regret Aversion: Effect of Expected Feedback on Risky Decision Making. Organizational Behavior and Human Decision Processes 65 (2), 148-158. 